\title{
ANTIAGING, ANTIOXIDANT FLAVONOIDS; SYNTHESIS, ANTIMICROBIAL SCREENING AS WELL AS 3D QSAR COMFA MODELS FOR THE PREDICTION OF BIOLOGICAL ACTIVITY
}

\author{
BILKIS JAHAN LUMBINY ${ }^{1}$, ZHANG HUI ${ }^{2}$ AND M. AZIZUL ISLAM \\ Department of Chemistry, Rajshahi University, Rajshahi-6205 \\ ${ }^{2}$ Department of Chemistry, Inha University, Incheon 402-751, Korea
}

\begin{abstract}
Flavonoids, polyphenolic heteronuclear compounds which are naturally occurring antioxidants are widely used as antiaging substances. Synthesis of new naturally occuring organic compounds with basic skeleton of chalcones, flavones and oxygenated flavones and their antimicrobial activity were reported by this research group for long. Presently comparative molecular field analysis (CoMFA) implemented in Sybyl 7.3 was conducted on a series of substituted flavones. CoMFA is an effective computer implemented 3D QSAR technique deriving a correlation between set of the biologically active molecules and their 3D shape, electrostatic and hydrogen bonding characteristics employing both interactive graphics and statistical techniques. Evaluation of 38 compounds were served to establish the models with grid spacing (2.0 $\AA$ ). CoMFA produced best predictive model for compound $1 \mathrm{C}$ ( 2 - Phenyl - 1,4 - benzopyrone) and compound 2C (5 - Fluoro - 3'hydroxy flavone ) among all. Model for compound $2 \mathrm{C}\left[\mathrm{r}^{2}\right.$ conv (no-validation) $=0.956, \mathrm{SEE}=$ $0.211, \mathrm{~F}$ value $=111.054)$ is better than that of compound $1 \mathrm{C}\left[\mathrm{r}^{2}\right.$ conv (no-validation) $=0.955$, $\mathrm{SEE}=0.212, \mathrm{~F}$ value $=110.261)$ but comparing superimposed model $1 \mathrm{C}$ being suggested as the best predictive model. $3 \mathrm{D}$ contour maps were generated to correlate the biological activities with the chemical structures of the examined compounds and for further design.
\end{abstract}

Key words: Antioxidant, 3D QSAR, CoMFA, Flavones, 3D contour map

\section{Introduction}

Flavonoids, the most common naturally occurring antioxidants are found ubiquitously in plants as pigments for flower coloration, in fruits, vegetables and beverages. Chemically flavonoids are polyphenolic, heteronucler compounds which are the characteristics of antioxidants. Antioxidants are compounds that protect cells against the damaging effects through the formation of phenoxy radical which combine with reactive oxygen species, such as superoxide, peroxyl radicals, hydroxyl radicals, and terminate the unwanted free radical chain reaction in cells. The flavonoids have aroused considerable interest recently because of their potential beneficial effects on human health specially its antiaging effect (Shirley 2001, Tapas et al. 2008 and Lee et al. 2011). A library of new naturally occuring organic compounds with basic skeleton of chalcones, flavones, and oxygenated flavones have been reported and their antimicrobial screening being carried out by this research

\footnotetext{
${ }^{1}$ Corresponding author: E-mail: blksjahan@yahoo.com
} 
group since last thirty years (Islam et al. 1980, Islam et al. 1981, Alam et al. 2004, Morshed et al. 2005 and Mostahar et al. 2006 and 2007). A general synthetic scheme being suggested (scheme 1) where by varying substituents several flavones can be obtained (eg, 4' - Methyl flavone, 4a, and 5,7- Dimethoxy - 4'- methyl flavones, 4b) with satisfactory percent yield. Antimicrobial screening usually being carried out against Gram positive bacteria (eg, $\mathrm{G}^{+}$, Bacillus megateriam), Gram negative bacteria (eg, $\mathrm{G}^{-}$, Escheria coli) by qualitative technique (Disk diffusion) and quantitative technique (Minimum Inhibitory Concentration). Most of the cases significnt biological activity was found and the variation in substituents can enhance the biological and medicinal activity and should be studied more to explore a single therapeutic tool for the treatment of cancer, cardiovascular, inflammatory diseases (Alam et al. 2004, Morshed et al. 2005 and Mostahar et al. 2006 and 2007).

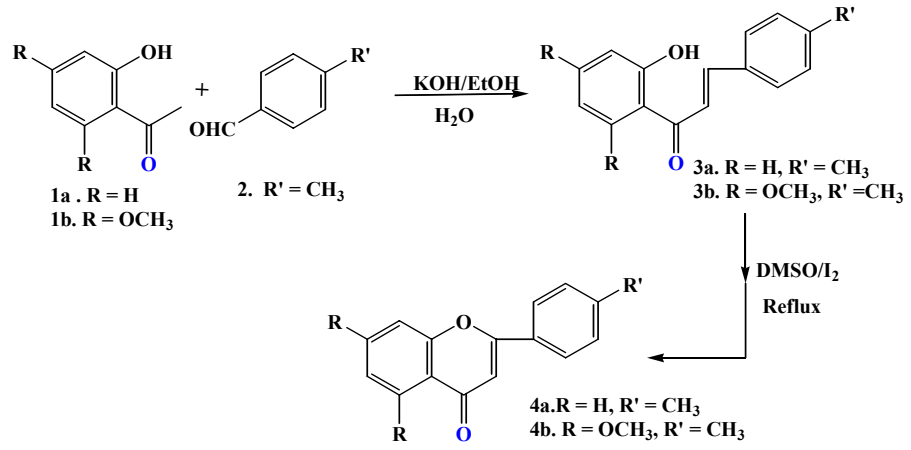

Scheme 1. Substituted acetophenon (1a, $\left.\mathrm{R}=\mathrm{H}, \mathbf{1 b}, \mathrm{R}=\mathrm{OCH}_{3}\right)$, substituted benzaldehyde (2, $\left.\mathrm{R}^{\prime}=\mathrm{CH}_{3}\right)$, produce the precursor of flavones, substituted chlacones $(\mathbf{3 a}, \mathrm{R}=\mathrm{H}, \mathbf{3} \mathbf{b}$, $\left.\mathrm{R}=\mathrm{OCH}_{3}\right)$ followed by the cyclisation to flavones $\left(\mathbf{4 a}, \mathrm{R}=\mathrm{H}, \mathbf{4} \mathbf{b}, \mathrm{R}=\mathrm{OCH}_{3}\right)$.

In addition, Comparative molecular field analysis (CoMFA) implemented in Sybyl 7.3 were conducted on a series of substituted flavones (Fig. 1). CoMFA is an effective computer implemented 3D QSAR technique deriving a correlation between the set of biologically active molecules and their 3D shape, electrostatic and hydrogen bonding characteristics employing both interactive graphics and statistical techniques. Classical QSAR correlates biological activities of drugs with physicochemical properties or indicator variables which encode certain structural features (Patrick 2001, Young 2001, Samee et al. 2004 and Putambaker et al. 2006). CoMFA is a powerful 3D QSAR method which has already shown its practical value in many cases. Most of the applications are in the field of ligand-protein interactions, describing affinity, inhibition constant, and also to correlate steric and electronic parameter (Patrick 2001). The molecules, which showed high activity results such as $\mathrm{K}_{\mathrm{i}}, \mathrm{IC}_{50}$ values are required. Charges should be added to the 
molecules so that electrostatic energy can be determined (Young 2001). A good alignment is the single most important part of doing a CoMFA analysis. The common substructures should have the same conformation in all molecules, and other parts should be superimposed as much as possible by adjusting internal torsional angles. Evaluation of 38 compounds (Fig. 1 and Table 1) was served to establish the models with grid spacing $(2.0 \AA)$ is to find the best predictive model.

\section{Materials and Methods}

CoMFA Precedure (Patrick 2001, Young 2001, Samee et al. 2004 and Putambaker et al. 2006): CoMFA describes 3D structure- activity relationship in a quantitative manner. For this purpose, a set of 38 derivative compounds of flavones (Fig. 1 and Table 1) have been constructed. Each of the structure is provided with charges (Minimization Process, scheme 2). Each of the molecules is saved and Molecular database (MDB) is created.

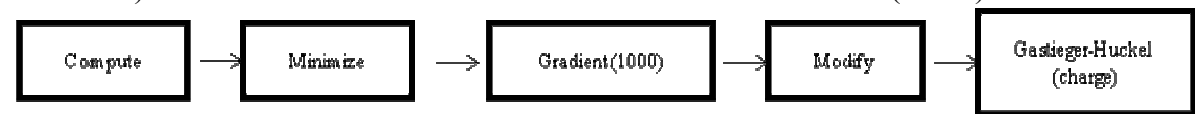

Scheme 2. Least energised structure determining process.

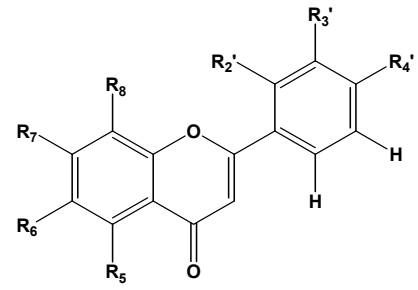

Fig. 1. Substitued flavones for CoMFA Analysis ( $\mathrm{R}$ values are presented in Table 1).

Database Alignment (Young 2001, Samee et al. 2004 and Putambaker et al. 2006): As one of the most important preconditions, all molecules have to interact with the same kind of receptor in the same manner so each conformation is taken in turn, and the molecular fields (steric and electrostatic) around it are measured at the lattice points of a regular Cartesian 3D grid; the lattice spacing is typically $2 \AA$. The "measured" interaction is between the molecule and a probe atom (an $\mathrm{sp}^{3}$-hybridised carbon with +1 charge ). In the next step, a certain subgroup of molecules are selected which constitutes a training set to derive the CoMFA model. The residual molecules are considered to be a test set which independently proves the validity of the derived model. A pharmacophore hypothesis is derived to orient the superposition of all individual molecules and to afford a rational and consistent alignment. The best superimposed alignment structure for compound 1C (2 Phenyl - 1,4 - benzopyrone) and compound 2C (5 - Fluoro - 3'- hydroxy flavone) have been shown in Figs. 2 and 3 respectively. 
Table 1. Substituted flavone Compounds in this study and their BZ (Benzodiazopine) site binding affinities [- $\log K_{i}, K_{i}$ in nM] (Huang et al. 2001).

\begin{tabular}{|c|c|c|c|c|c|c|c|c|}
\hline Compound & $\mathrm{R}_{5}$ & $\mathrm{R}_{6}$ & $\mathrm{R}_{7}$ & $\mathrm{R}_{8}$ & $\mathrm{R}_{2}^{\prime}$ & $\mathrm{R}_{3}{ }^{\prime}$ & $\mathrm{R}_{4}^{\prime}$ & $-\log K_{i}$ \\
\hline $1 \mathrm{C}$ & $-\mathrm{H}$ & $-\mathrm{H}$ & $-\mathrm{H}$ & $-\mathrm{H}$ & $-\mathrm{H}$ & $-\mathrm{H}$ & $-\mathrm{H}$ & 6.00 \\
\hline $2 \mathrm{C}$ & $-\mathrm{H}$ & $-F$ & $-\mathrm{H}$ & $-\mathrm{H}$ & $-\mathrm{H}$ & $-\mathrm{OH}$ & $-\mathrm{H}$ & 5.60 \\
\hline $3 \mathrm{C}$ & $-\mathrm{H}$ & $-\mathrm{Cl}$ & $-\mathrm{H}$ & $-\mathrm{H}$ & $-\mathrm{H}$ & $-\mathrm{OH}$ & $-\mathrm{H}$ & 6.07 \\
\hline $4 \mathrm{C}$ & $-\mathrm{H}$ & $-\mathrm{Br}$ & $-\mathrm{H}$ & $-\mathrm{H}$ & $-\mathrm{H}$ & $-\mathrm{OH}$ & $-\mathrm{H}$ & 6.22 \\
\hline $5 \mathrm{C}$ & $-\mathrm{H}$ & $-F$ & $-\mathrm{H}$ & $-\mathrm{H}$ & $-\mathrm{H}$ & $-\mathrm{NO}_{2}$ & $-\mathrm{H}$ & 6.74 \\
\hline $6 \mathrm{C}$ & $-\mathrm{H}$ & $-\mathrm{Cl}$ & $-\mathrm{H}$ & $-\mathrm{H}$ & $-\mathrm{H}$ & $-\mathrm{NO}_{2}$ & $-\mathrm{H}$ & 8.10 \\
\hline $7 \mathrm{C}$ & $-\mathrm{H}$ & $-\mathrm{Cl}$ & $-\mathrm{H}$ & $-\mathrm{H}$ & $-\mathrm{H}$ & $-\mathrm{H}^{2}$ & $-\mathrm{OCH}_{3}$ & 5.90 \\
\hline $8 \mathrm{C}$ & $-\mathrm{H}$ & $-\mathrm{Br}$ & $-\mathrm{H}$ & $-\mathrm{H}$ & $-\mathrm{H}$ & $-\mathrm{H}$ & $-\mathrm{OCH}_{3}$ & 5.68 \\
\hline $9 \mathrm{C}$ & $-\mathrm{H}$ & $-\mathrm{Br}$ & $-\mathrm{H}$ & $-\mathrm{H}$ & $-\mathrm{NO}_{2}$ & $-\mathrm{H}$ & $-\mathrm{H}$ & 6.68 \\
\hline $10 \mathrm{C}$ & $-\mathrm{H}$ & $-\mathrm{NO}_{2}$ & $-\mathrm{H}$ & $-\mathrm{H}$ & $-\mathrm{H}$ & $-\mathrm{H}$ & $-\mathrm{Br}$ & 7.60 \\
\hline $11 \mathrm{C}$ & $-\mathrm{H}$ & $-\mathrm{Cl}$ & $-\mathrm{H}$ & $-\mathrm{H}$ & $-F$ & $-\mathrm{H}$ & $-\mathrm{H}$ & 6.38 \\
\hline $12 \mathrm{C}$ & $-\mathrm{H}$ & $-\mathrm{Br}$ & $-\mathrm{H}$ & $-\mathrm{H}$ & $-F$ & $-\mathrm{H}$ & $-\mathrm{H}$ & 6.42 \\
\hline $13 \mathrm{C}$ & $-\mathrm{H}$ & $-\mathrm{H}$ & $-\mathrm{H}$ & $-\mathrm{H}$ & $-\mathrm{H}$ & $-F$ & $-\mathrm{H}$ & 5.45 \\
\hline $14 \mathrm{C}$ & $-\mathrm{H}$ & $-F$ & $-\mathrm{H}$ & $-\mathrm{H}$ & $-\mathrm{H}$ & $-F$ & $-\mathrm{H}$ & 6.04 \\
\hline $15 \mathrm{C}$ & $-\mathrm{H}$ & $-\mathrm{Cl}$ & $-\mathrm{H}$ & $-\mathrm{H}$ & $-\mathrm{H}$ & $-F$ & $-\mathrm{H}$ & 6.93 \\
\hline $16 \mathrm{C}$ & $-\mathrm{H}$ & $-\mathrm{Br}$ & $-\mathrm{H}$ & $-\mathrm{H}$ & $-\mathrm{H}$ & $-F$ & $-\mathrm{H}$ & 7.38 \\
\hline $17 \mathrm{C}$ & $-\mathrm{H}$ & $-\mathrm{H}$ & $-\mathrm{H}$ & $-\mathrm{H}$ & $-\mathrm{H}$ & $-\mathrm{H}$ & $-F$ & 5.44 \\
\hline $18 \mathrm{C}$ & $-\mathrm{H}$ & $-F$ & $-\mathrm{H}$ & $-\mathrm{H}$ & $-\mathrm{H}$ & $-\mathrm{H}$ & $-F$ & 5.60 \\
\hline $19 \mathrm{C}$ & $-\mathrm{H}$ & $-\mathrm{Cl}$ & $-\mathrm{H}$ & $-\mathrm{H}$ & $-\mathrm{H}$ & $-\mathrm{H}$ & $-F$ & 6.74 \\
\hline $20 \mathrm{C}$ & $-\mathrm{H}$ & $-\mathrm{Br}$ & $-\mathrm{H}$ & $-\mathrm{H}$ & $-\mathrm{H}$ & $-\mathrm{H}$ & $-F$ & 6.94 \\
\hline $21 \mathrm{C}$ & $-\mathrm{H}$ & $-\mathrm{H}$ & $-\mathrm{H}$ & $-\mathrm{H}$ & $-\mathrm{H}$ & $-\mathrm{Cl}$ & $-\mathrm{H}$ & 6.21 \\
\hline $22 \mathrm{C}$ & $-\mathrm{H}$ & $-F$ & $-\mathrm{H}$ & $-\mathrm{H}$ & $-\mathrm{H}$ & $-\mathrm{Cl}$ & $-\mathrm{H}$ & 6.70 \\
\hline $23 \mathrm{C}$ & $-\mathrm{H}$ & $-\mathrm{Cl}$ & $-\mathrm{H}$ & $-\mathrm{H}$ & $-\mathrm{H}$ & $-\mathrm{Cl}$ & $-\mathrm{H}$ & 7.64 \\
\hline $24 \mathrm{C}$ & $-\mathrm{H}$ & $-\mathrm{Br}$ & $-\mathrm{H}$ & $-\mathrm{H}$ & $-\mathrm{H}$ & $-\mathrm{Cl}$ & $-\mathrm{H}$ & 7.77 \\
\hline $25 \mathrm{C}$ & $-\mathrm{H}$ & $-\mathrm{H}$ & $-\mathrm{H}$ & $-\mathrm{H}$ & $-\mathrm{H}$ & $-\mathrm{Br}$ & $-\mathrm{H}$ & 6.38 \\
\hline $26 \mathrm{C}$ & $-\mathrm{H}$ & $-F$ & $-\mathrm{H}$ & $-\mathrm{H}$ & $-\mathrm{H}$ & $-\mathrm{Br}$ & $-\mathrm{H}$ & 6.63 \\
\hline $27 \mathrm{C}$ & $-\mathrm{H}$ & $-\mathrm{Cl}$ & $-\mathrm{H}$ & $-\mathrm{H}$ & $-\mathrm{H}$ & $-\mathrm{Br}$ & $-\mathrm{H}$ & 7.64 \\
\hline $28 \mathrm{C}$ & $-\mathrm{H}$ & $-\mathrm{Br}$ & $-\mathrm{H}$ & $-\mathrm{H}$ & $-\mathrm{H}$ & $-\mathrm{Br}$ & $-\mathrm{H}$ & 7.72 \\
\hline $29 \mathrm{C}$ & $-\mathrm{H}$ & $-\mathrm{Br}$ & $-\mathrm{H}$ & $-\mathrm{H}$ & $-\mathrm{H}$ & $-\mathrm{H}$ & $-\mathrm{H}$ & 7.15 \\
\hline $30 \mathrm{C}$ & $-\mathrm{H}$ & $-\mathrm{Br}$ & $-\mathrm{H}$ & $-\mathrm{H}$ & $-\mathrm{H}$ & $-\mathrm{H}$ & $-\mathrm{NO}_{2}$ & 6.70 \\
\hline $31 \mathrm{C}$ & $-\mathrm{H}$ & $-\mathrm{NO}_{2}$ & $-\mathrm{H}$ & $-\mathrm{H}$ & $-\mathrm{H}$ & $-\mathrm{NO}_{2}$ & $-\mathrm{H}^{2}$ & 7.92 \\
\hline $32 \mathrm{C}$ & $-\mathrm{H}$ & $-\mathrm{Br}^{2}$ & $-\mathrm{H}$ & $-\mathrm{H}$ & $-\mathrm{H}$ & $-\mathrm{NO}_{2}$ & $-\mathrm{H}$ & 9.00 \\
\hline $33 \mathrm{C}$ & $-\mathrm{OH}$ & $-\mathrm{Br}$ & $-\mathrm{OH}$ & $-\mathrm{Br}$ & $-\mathrm{H}$ & $-\mathrm{H}^{2}$ & $-\mathrm{H}$ & 6.15 \\
\hline $34 \mathrm{C}$ & $-\mathrm{OH}$ & $-\mathrm{H}$ & $-\mathrm{OH}$ & $-\mathrm{H}$ & $-\mathrm{H}$ & $-\mathrm{H}$ & $-\mathrm{H}$ & 5.52 \\
\hline $35 \mathrm{C}$ & $-\mathrm{OH}$ & $-\mathrm{H}$ & $-\mathrm{OH}$ & $-\mathrm{H}$ & $-\mathrm{H}$ & $-\mathrm{H}$ & $-\mathrm{OH}$ & 5.52 \\
\hline $36 \mathrm{C}$ & $-\mathrm{OH}$ & $-\mathrm{H}$ & $-\mathrm{OH}$ & $-\mathrm{H}$ & $-\mathrm{Cl}$ & $-\mathrm{H}$ & $-\mathrm{H}$ & 5.10 \\
\hline $37 \mathrm{C}$ & $-\mathrm{OH}$ & $-\mathrm{H}$ & $-\mathrm{OH}$ & $-\mathrm{H}$ & $-F$ & $-\mathrm{H}$ & $-\mathrm{H}$ & 5.10 \\
\hline $38 \mathrm{C}$ & $-\mathrm{OH}$ & $-\mathrm{OCH}_{3}$ & $-\mathrm{OH}$ & $-\mathrm{H}$ & $-\mathrm{H}$ & $-\mathrm{H}$ & $-\mathrm{OH}$ & 6.00 \\
\hline
\end{tabular}

Statistical analysis: It includes statistical averages of all possible interactions of the probe molecule and others. These sort of processes can be modelled on a molecular level by obtaining many results and then using a statistical distribution of those results. Partial Least Square (PLS) analysis is the most appropriate method for this purpose. The value of the resulting QSAR can be determined through the cross validated $\mathrm{r}^{2}$ (referred to as $\mathrm{q}^{2}$ ) reported by the PLS (Table 3 ). If acceptable, The CoMFA rederived in final in non cross validated form (referred to as $\mathrm{r}^{2}$ in Table 3 ). 
Equations: 3D properties of a molecule are considered as a whole, size, shape, electronic properties etc. Biological activities correlate the physicochemical properties (hydrophobicity) in following way:

$$
\begin{aligned}
\log (1 / \mathrm{C})= & \log \mathrm{P}(\text { partition coefficient })+\mathrm{k}_{2} \sigma(\text { electronic effect }) \\
& \left.+\mathrm{k}_{3} \text { Es (steric effect }\right)+\mathrm{k}_{4} \quad \text { (1) [simple relation] }
\end{aligned}
$$

It can be represented by the following Matrix

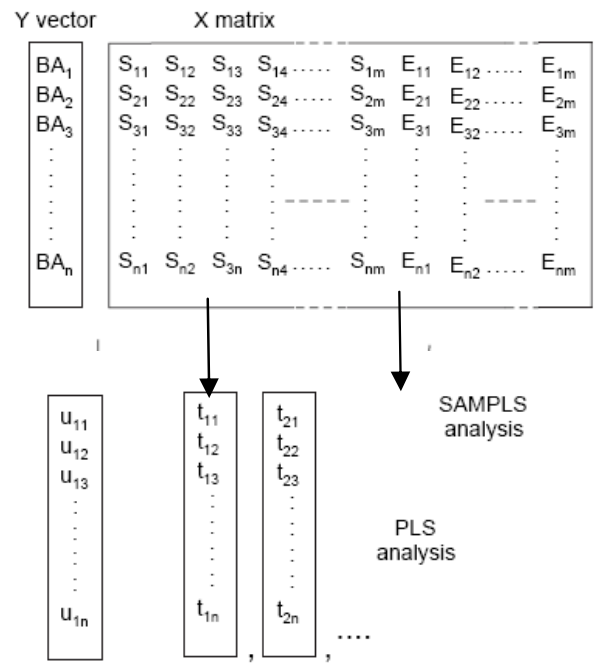

It can be written as

$$
\begin{aligned}
\mathrm{BA}_{\mathrm{i}}= & \mathrm{a}_{1} \mathrm{~S}_{\mathrm{i} 1}+\mathrm{a}_{2} \mathrm{~S}_{\mathrm{i} 2}+\mathrm{a}_{3} \mathrm{~S}_{\mathrm{i} 3}+\ldots . .+\mathrm{a}_{\mathrm{m}} \mathrm{S}_{\mathrm{im}}+ \\
& +\mathrm{b}_{1} \mathrm{E}_{\mathrm{i} 1}+\mathrm{b}_{2} \mathrm{E}_{\mathrm{i} 2}+\mathrm{b}_{3} \mathrm{E}_{\mathrm{i} 3}+\ldots . .+\mathrm{b}_{\mathrm{m}} \mathrm{E}_{\mathrm{im}}
\end{aligned}
$$

[PLS analysis derives vectors from the $\mathrm{Y}$ block; $\mathrm{BA}_{\mathrm{i}}=$ logarithm of realative affinities or other biological activities and the $X$ block; $S_{i j}=$ steric field variable of molecule $i$ in the grid point $j, E_{i j}=$ electrostatic field variable of molecule $i$ in the grid point $j$ ]

\section{Results and Discussion}

The best CoMFA predictive model is suggested by varying common substructures (in Table 2 for compound 1C) for all 38 compounds are presented in Table 3. For better PLS result the search of proper common substructure during molecular alignment is a vital part. Based on regression and statiscal error from Table 2, 1C (ii) being selected as common substructure for all the molecules during PLS analysis. As 3D properties of a molecule are considered as a whole, size, shape, electronic properties so 1C (2 - Phenyl - 
1, 4 - benzopyrone) and compound 2C (5 - Fluoro - 3'- hydroxy flavone) presented in Table 3 showed better results among all. Model for compound $2 \mathrm{C}\left[\mathrm{r}^{2}\right.$ conv (no-validation) $=$ $0.956, \mathrm{SEE}=0.211, \mathrm{~F}$ value $=111.054)$ is better than that of compound $1 \mathrm{C}\left[\mathrm{r}^{2}\right.$ conv (novalidation $)=0.955, \mathrm{SEE}=0.212, \mathrm{~F}$ value $=110.261)$. But if we compare the superimposed Figures (Fig. 2 for $1 \mathrm{C}$ and Fig. 2 for 2C) the best superimposed model is $1 \mathrm{C}$ (Fig. 2). So the best predictive model being suggested as compound $1 \mathrm{C}$ with common substructure $1 \mathrm{C}(\mathrm{ii})$.

Table 2. For better PLS results the search of common substructures observed during molecular alignment of compound $1 \mathrm{C}$.

\begin{tabular}{|c|c|c|c|c|}
\hline $\begin{array}{l}\text { Selected } \\
\text { substructures }\end{array}$ & $1 \mathrm{C}(\mathrm{i})$ & $1 \mathrm{C}$ (ii) & $\int_{\mathrm{R}_{s}}^{0} \mathrm{O}_{0}^{0}$ & 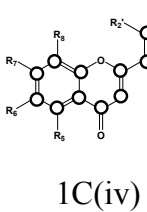 \\
\hline $\begin{array}{c}\text { No. of } \\
\text { Components }^{a}\end{array}$ & & & & \\
\hline Set & 6 & 6 & 6 & 6 \\
\hline Obtained & 6 & 3 & 3 & 3 \\
\hline $\begin{array}{c}\text { Cross validation } \\
\mathrm{q}^{2} \\
\text { No validation }\end{array}$ & 0.710 & 0.743 & 0.722 & 0.738 \\
\hline $\mathrm{R}^{2}$ & 0.933 & 0.955 & 0.947 & 0.953 \\
\hline $\mathrm{SEE}^{b}$ & 0.261 & 0.213 & 0.232 & 0.217 \\
\hline $\mathrm{F}$ value & 71.512 & 110.261 & 91.835 & 105.608 \\
\hline
\end{tabular}

${ }^{a}$ Set component no. 6-13 and column filtering $0.5-2 \mathrm{kcal} / \mathrm{mol}$ giving similar results, ${ }^{b}$ Standard Error of Estimation.

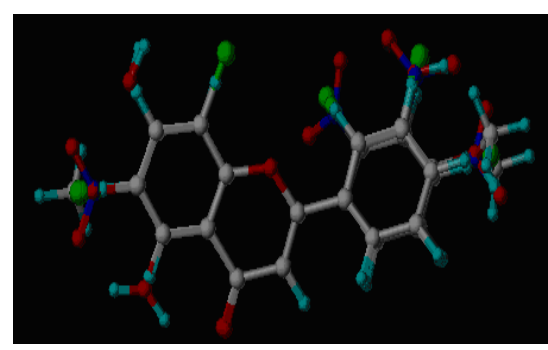

Fig. 2. Alignment picture for compound $1 \mathrm{C}$.

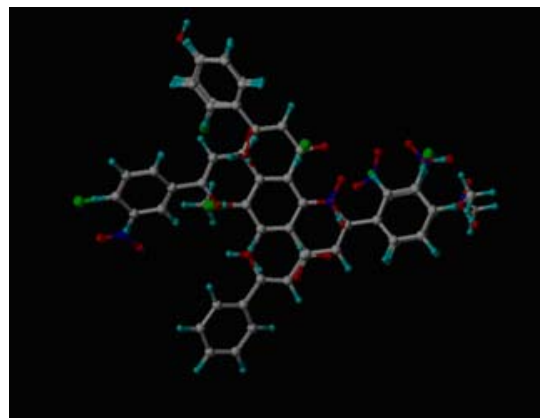

Fig. 3. Alignment picture for compound 2C. 
Table 3. PLS Analysis results for aligning 38 substituted flavones by Sybyl 7.3.

\begin{tabular}{|c|c|c|c|c|c|c|}
\hline \multirow[t]{2}{*}{ Compounds } & \multirow{2}{*}{$\begin{array}{c}\text { Min. energy } \\
\text { Ges-Huck } \\
\text { model }(\mathrm{kcal} / \mathrm{mol})\end{array}$} & \multirow{2}{*}{$\begin{array}{l}\text { No. of } \\
\text { compo } \\
\text { nents }\end{array}$} & \multirow{2}{*}{$\begin{array}{c}\text { Cross } \\
\text { validation } \\
\mathrm{q} 2 \\
\end{array}$} & \multicolumn{2}{|c|}{ No Validation } & \multirow[t]{2}{*}{ F value } \\
\hline & & & & $\mathrm{R}^{2}$ & SEE & \\
\hline $01 \mathrm{C}$ & 4.461 & 3 & 0.743 & 0.955 & 0.213 & 110.261 \\
\hline $02 \mathrm{C}$ & 1.537 & 6 & 0.815 & 0.956 & 0.212 & 111.054 \\
\hline $03 \mathrm{C}$ & 2.408 & 6 & 0.811 & 0.954 & 0.216 & 106.710 \\
\hline $04 \mathrm{C}$ & 2.523 & 6 & 0.787 & 0.940 & 0.247 & 80.991 \\
\hline $05 \mathrm{C}$ & 3.990 & 6 & 0.693 & 0.917 & 0.291 & 56.746 \\
\hline $06 \mathrm{C}$ & 4.863 & 4 & 0.778 & 0.945 & 0.236 & 88.448 \\
\hline $07 \mathrm{C}$ & 4.618 & 6 & 0.666 & 0.949 & 0.228 & 95.654 \\
\hline $08 \mathrm{C}$ & 4.724 & 6 & 0.531 & 0.874 & 0.357 & 35.844 \\
\hline $09 \mathrm{C}$ & 5.386 & 4 & 0.771 & 0.956 & 0.212 & 111.738 \\
\hline $10 \mathrm{C}$ & 5.373 & 5 & 0.804 & 0.937 & 0.253 & 76.317 \\
\hline $11 \mathrm{C}$ & 2.069 & 4 & 0.804 & 0.961 & 0.199 & 127.206 \\
\hline $12 \mathrm{C}$ & 2.172 & 6 & 0.777 & 0.937 & 0.252 & 77.270 \\
\hline $13 \mathrm{C}$ & 2.818 & 6 & 0.711 & 0.931 & 0.265 & 69.386 \\
\hline $14 \mathrm{C}$ & 0.589 & 6 & 0.701 & 0.931 & 0.264 & 69.814 \\
\hline $15 \mathrm{C}$ & 1.457 & 6 & 0.712 & 0.930 & 0.267 & 68.471 \\
\hline $16 \mathrm{C}$ & 1.575 & 6 & 0.712 & 0.930 & 0.267 & 68.377 \\
\hline $17 \mathrm{C}$ & 3.699 & 6 & 0.703 & 0.930 & 0.266 & 69.054 \\
\hline $18 \mathrm{C}$ & 1.462 & 6 & 0.703 & 0.930 & 0.265 & 69.155 \\
\hline $19 \mathrm{C}$ & 2.334 & 6 & 0.702 & 0.930 & 0.266 & 69.051 \\
\hline $20 \mathrm{C}$ & 2.453 & 6 & 0.702 & 0.930 & 0.266 & 69.009 \\
\hline $21 \mathrm{C}$ & 4.461 & 6 & 0.786 & 0.934 & 0.258 & 73.235 \\
\hline $22 \mathrm{C}$ & 1.537 & 6 & 0.777 & 0.945 & 0.239 & 86.127 \\
\hline $23 \mathrm{C}$ & 2.408 & 6 & 0.778 & 0.942 & 0.243 & 83.359 \\
\hline $24 \mathrm{C}$ & 2.523 & 6 & 0.769 & 0.941 & 0.245 & 81.937 \\
\hline $25 \mathrm{C}$ & 3.990 & 6 & 0.774 & 0.942 & 0.243 & 83.843 \\
\hline $26 \mathrm{C}$ & 4.863 & 4 & 0.720 & 0.953 & 0.218 & 104.762 \\
\hline $27 \mathrm{C}$ & 4.618 & 4 & 0.720 & 0.953 & 0.218 & 104.770 \\
\hline $28 \mathrm{C}$ & 4.724 & 4 & 0.720 & 0.953 & 0.218 & 104.757 \\
\hline $29 \mathrm{C}$ & 5.386 & 4 & 0.720 & 0.953 & 0.218 & 104.782 \\
\hline $30 \mathrm{C}$ & 5.373 & 6 & 0.740 & 0.900 & 0.319 & 46.436 \\
\hline $31 \mathrm{C}$ & 2.069 & 6 & 0.691 & 0.895 & 0.327 & 43.895 \\
\hline $32 \mathrm{C}$ & 2.172 & 6 & 0.762 & 0.944 & 0.238 & 87.011 \\
\hline $33 \mathrm{C}$ & 2.818 & 6 & 0.684 & 0.916 & 0.291 & 56.465 \\
\hline $34 \mathrm{C}$ & 0.589 & 6 & 0.724 & 0.936 & 0.255 & 75.500 \\
\hline $35 \mathrm{C}$ & 1.457 & 6 & 0.732 & 0.942 & 0.243 & 83.222 \\
\hline $36 \mathrm{C}$ & 1.575 & 4 & 0.726 & 0.949 & 0.227 & 96.768 \\
\hline $37 \mathrm{C}$ & 3.699 & 4 & 0.736 & 0.946 & 0.235 & 89.996 \\
\hline $38 \mathrm{C}$ & 9.722 & 6 & 0.456 & 0.888 & 0.337 & 41.030 \\
\hline
\end{tabular}

The result of this analysis is presented as a set of contour maps. These contour maps show favourable and unfavourable steric regions around the molecules as well as favourable 
and unfavorable regions for electropositive and electronegative substituents in certain positions. Predictions for the compounds not included in the analysis can be made by calculating the fields of this molecules and by inserting the grid values into the PLS model. 3D contour maps were generated to correlate the biological activities with the chemical structures of the examined compounds and for further design. Steric contour map for 1C (Fig. 4) is shown by (a) and (b) polyhedra. Polyhedra (a) indicate region where more steric bulk will enhance the activity and arround polyhedra (b) less steric bulk will enhance the activity. The variation in substituents can enhance the biological and medicinal activity and should be studied more to explore the moleclar drug design.

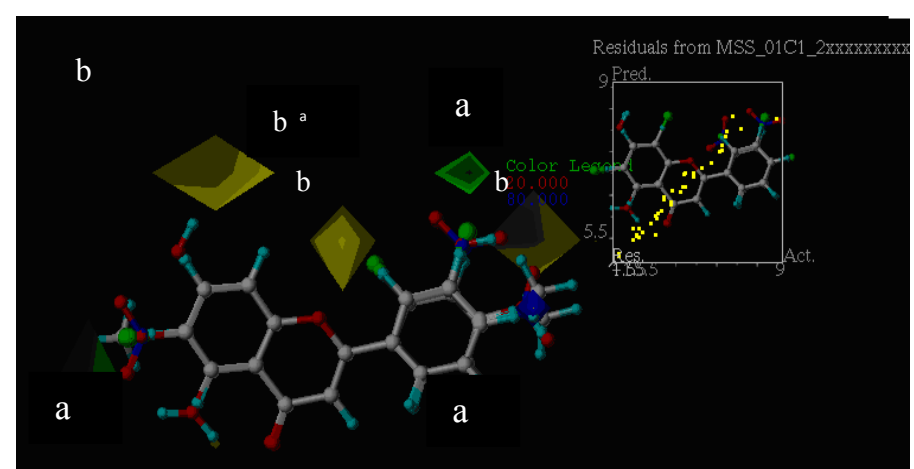

Fig. 4: CoMFA contour maps for compound 1C.

\section{Acknowledgement}

A portion of the experimental study was carried out in Molecular Drug Design and Chemical Kinetics Laboratory, Inha University, South Korea.

\section{References}

Alam, S., A. Islam and N. C. Das. 2004. Synthesis of maximaflavanone-A and its derivative. Journal of Bangladesh Academy of Science. 28 (2): 117.

Huang, X., T. Liu, J. Gu, X. Luo, R. Ji, Y. Cao, H. Xue, J. T. Wong, B. L. Wong, G. Pei, H. Jiang and K. Chen. 2001. 3D-QSAR Model of Flavonoids Binding at Benzodiazepine Site in GABA $_{A}$ Receptors. J. Med. Chem. 44:1883-1891.

Lee, E., I. Jang, M. J. Shin, H. J. Cho, J. Kim, J. E. Eom, Y. Kwon and Y. Na. 2011. Chalcones as Novel Non-Pepditic $\mu$-Calpain Inhibitors. Bull. of Korean Chem. Soc. 32(9): 3459.

Islam, M. A., R. K. Gupta and M. Krishnamurti. 1980. Furano chalcone and prenylated flavanones from Milletia Ovalifolia Seeds. Phytochemistry. 19: 1558-1559.

Islam, M. A., R. K. Gupta and M. Krishnamurti. 1981. New synthesis of ovaliflavanone-A, ovaliflavanone-B and ovalichromene-B. Indian J. Chem. 20B: 21-22.

Morshed, M. H., M. S. Hossain, M. Ibrahim, M. Z. Shafique, M. O. H. Helali, A. Samad, M. S. Islam and M. A. Islam. 2005. Bacteria killing kinetics of the four plant hormones. Pakisthan Journal of Biological Science. 8 (7): 1025. 
Mostahar, S., P. Khatun and M. A. Islam. 2007. Synthesis of two vanillin ring containing flavones by different methods and studies of their antibacterial and antifungal activities. Journal of Biological Science. 7(3): 514-519.

Mostahar, S., S. Alam and M. A. Islam. 2006. Cytotoxic and antimicrobial activities of some synthetic flavanones. Indian Journal of Chemistry. 45B: 478-486.

Patrick, G. L. 2001. An Introduction to Medicinal Chemistry. Oxford University Press. U. K. 450465.

Putambaker, D. S., R. Giridhar and M. R. Yadav. 2006. 3D-QSAR CoMFA/CoMSIA studies on 5aryl-2, 2-dialkyl-4-phenyl-3 (2H)-furanone derivatives as selective COX-2 Inhibitors. Acta Pharm. 56: 157-174.

Samee, W., J. Ungwitayatorn, C. Matayatsk and J. Pimthon. 2004. 3D-QSAR Studies on Phthalimide Derivatives as HIV-1Reverse Transcriptase Inhibitors. Science Asia. 30: 8188 .

Shirley, B.W. 2001. Flavonoid Biosynthesis. A colorful Model for Genetics, Biochemistry, Cell Biology, Biotechnology. Plant Physiology. 126: 485-493.

Tapas, A. R., D. M. Sharker and R.B. Kakde. 2008. Flavonoids as Neutraceuticals: A Review. Tropical Journal of Pharmaceutical Research. 7(3): 1089-1099.

Young, D. C. 2001. Computational Chemistry; A Practical Guide for Applying Techniques to RealWorld Problems; John Willy and Sons. 243-249.

(Received revised manuscript on 24 October 2013) 